Historic, Archive Document

Do not assume content reflects current scientific knowledge, policies, or practices. 

1.9622

N25t22

erp. 2

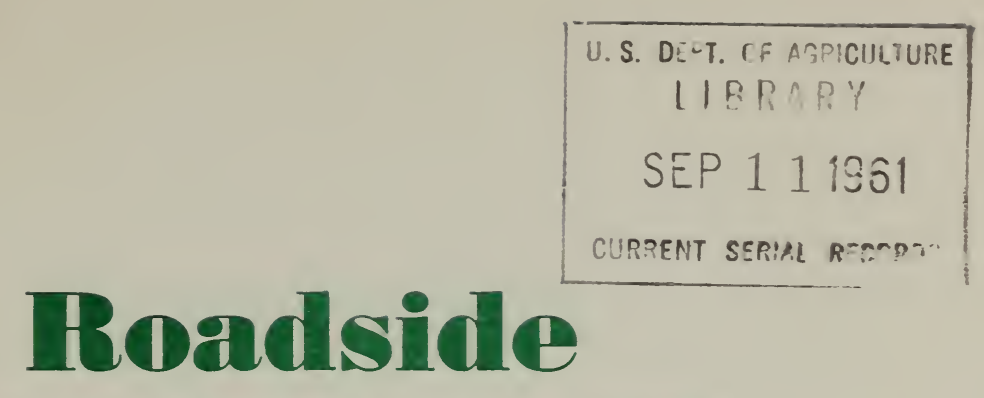

Brousli

Cominol.

with 2,4,5-T on Eastern National Forests

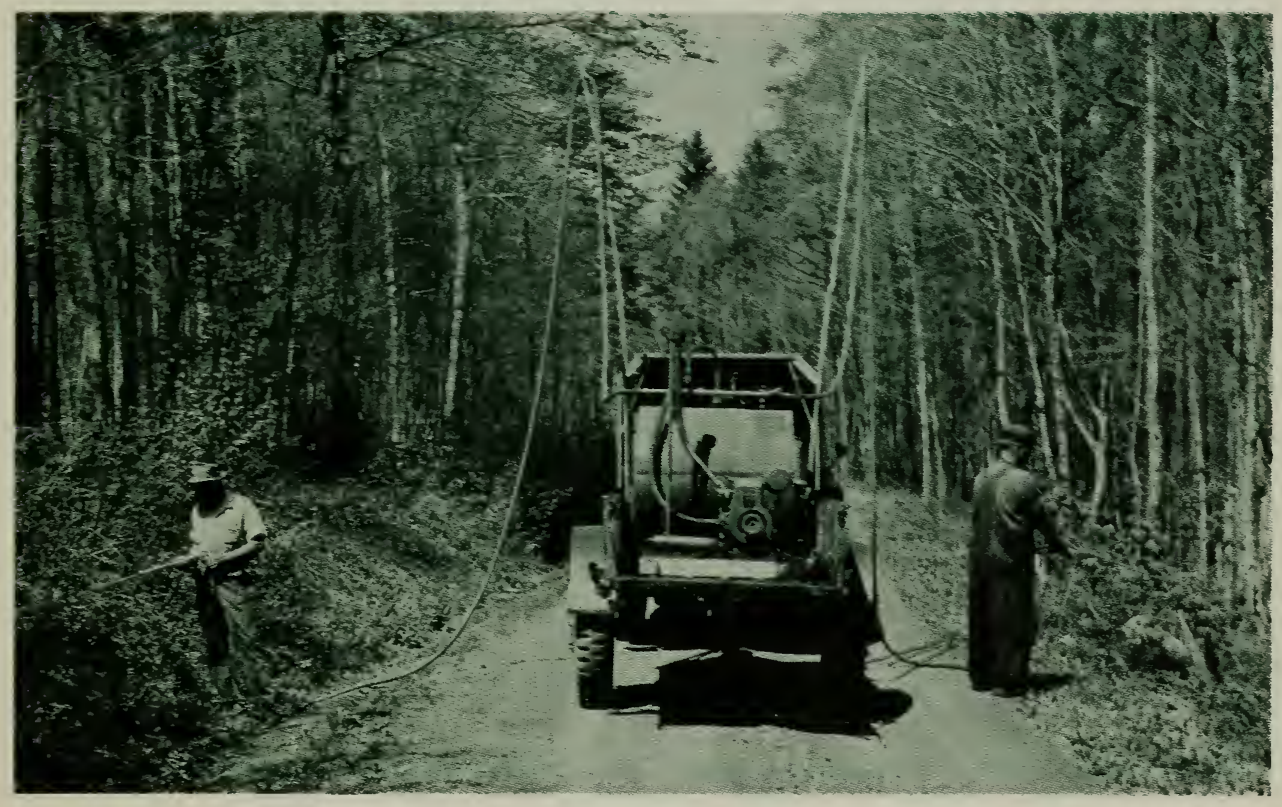

by W. E. McQuilkin \& L. H. Strickenberg 



\title{
Toadside
}

\section{British Control}

\section{with 2,4,5-T on Eastern National Forests}

\author{
by W. E. Mequilkin \& L. R. Strickenberg
}

\section{About the Authors ...}

WILLIAII E. McQUILKIN did his undergraduate work at Doane College in Nebraska, and later received M.A. and Ph.D. degrees in plant ecology respectively at the University of Nebraska and the University of Pennsylvania. He joined the Appalachian (now Southeastern) Station of the Forest Service in 1937, transferring to the Northeastern Station in 1942. The experiments described in this paper mostly were done while he was stationed at the former Kingston Research Center in Pennsylvania. Since 1954 he has been assistant chief in the Division of Forest Management Research at the Experiment Station headquarters in Upper Darby.

L. R. STRICKENBERG was graduated from the Pennsylvania State University in Civil Engineering. After graduation he was employed by the National Bureau of Standards in Washington as a mechanical engineer. He joined the J. S. Forest Service in 1923 in the land-acquisition program, holding assignments as chief land examiner and forest engineer. Since 1942 he has been assigned to the Eastern Regional Office as engineer in charge of equipment management. Mr. Strickenberg has done considerable work in the development of special equipment adapted for Forest Service work such as the spraying equipment described in this paper. 



\section{The Roadside Problem}

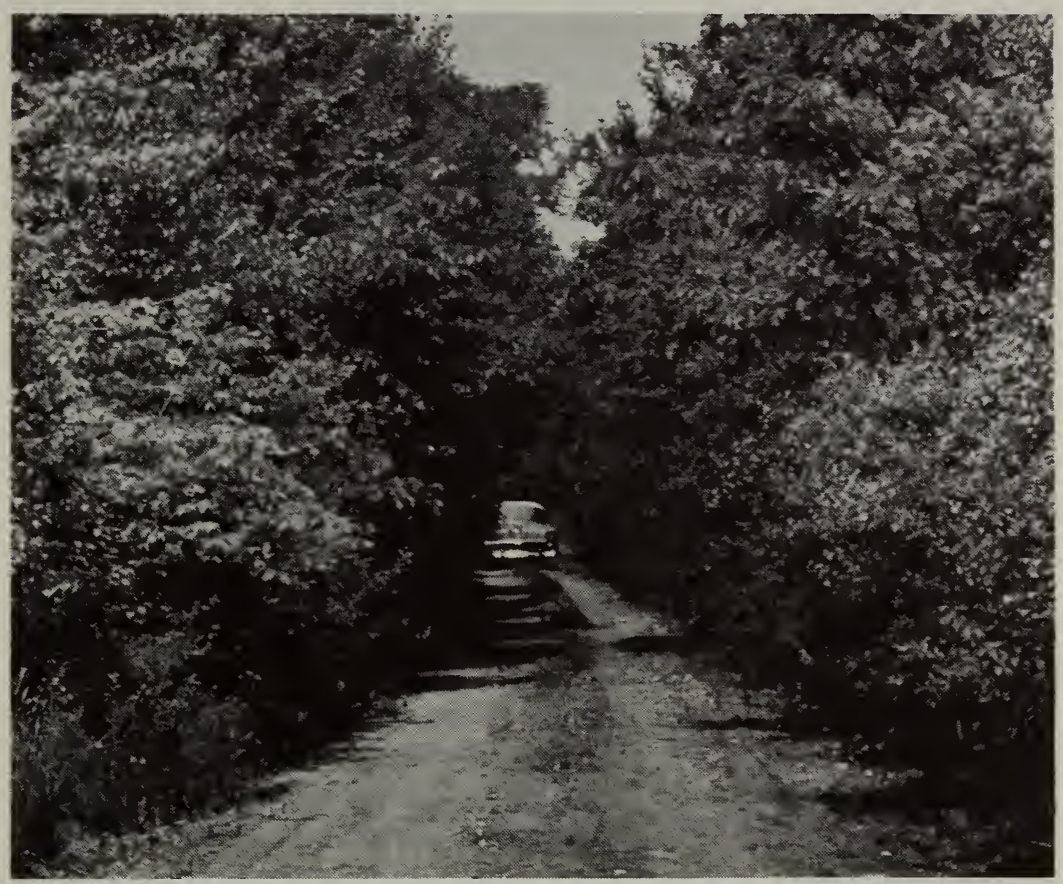

Figure 1.--The need for roadside brush control. Without control of some sort, trees and brush encroach on forest roads, as shown by this town road in Maine. Cars are scratched, passing is made difficult, and visibility on curves is dangerously reduced.

AINTENANCE standards for roads within the national forests in the East have, until recently, included annual mowing of the shoulders. One or occasionally two passes with a mower carrying a 5-foot cutter bar were made on each side of the road. Costs for this kind of operation were about $\$ 16$ per road mile per year.

The big problem was tree species, especially hardwoods. If allowed to grow for a few years, the woody stems attain such size that they lean over the roadway, brushing 
cars, obstructing the view, inviting snow and ice breakage, and interfering with ditch drainage (fig. 1). Many such stems become too thick at the base for clipping with a mower --hence the practice of annual mowing.

Since most of the eastern hardwood species sprout vigorously after cutting, the density of hardwood growth tends to increase under a mowing regime: several sprouts often develop where but one grew before. In addition, the sprouts from established plants are continually being reinforced to varying degrees by new seedlings. These are clipped by the mower, resprout, are clipped again, and in a few years become multistemmed clumps. Thus mowing fails to improve the brush situation, except temporarily: in the long run it tends to intensify the problem.

About a decade ago, forest engineers in both the Washington and the Region $7^{1}$ offices of the U. S. Forest Service were becoming increasingly concerned about the burdensome workload and costs involved in annual mowing of the roadside brush. On utility right-of-ways and in various other situations, chemical herbicides were coming into increasing use for brush control. Could the brush-control job on the national forest roads be done more easily and at lower cost with chemicals than by mowing?

In 1951 Region 7 and the Northeastern Forest Experiment Station undertook to answer that question through a program of cooperative tests conducted on national forest roads with national forest labor and equipment. The test phase of this work extended through 1955 . The results were sufficiently favorable that Region 7 immediately embarked in 1956 upon a 5-year regional plan for converting from mowing to chemical control.

This report contains a resume of the testing phase of the program in regard to chemicals and application methods; a description of the equipment now being used; and a general appraisal of chemical control in practice on the national forests.

\footnotetext{
${ }^{1}$ Region 7 is an administrative unit of the U. S. Forest Service, serving the New England States, Middle At lantic States, Virginia, West Virginia, and Kentucky.
} 


\section{The Test Phase 1951-1955}

When this work was started in 1951, much less was known about the efficacy of different herbicides and application methods than is known today. For instance, 2, 4, 5-T still was fairly new; and the merits of basal stem spraying with oil solutions were just beginning to be recognized. So it was appropriate at that time to conduct tests that now would have little justification. And, because much of the technical information derived from those tests today is common knowledge among brush control workers, some aspects of the testing program will be described only in rather general terms.

\section{CHEMICALS AND METHODS}

The first tests were conducted on the Gale River Experimental Forest in the White Mountain National Forest in New Hampshire. In a sense, these were screening tests involving mainly ammate and a 'brush-killer' mixture of 2, 4-D and 2,4,5-T applied at different seasons and at different concentrations; the brush-killer mixture also was used in both water and oil carriers. In the main tests a treatment unit was about $1 / 4$ mile of roadside. In addition, several other herbicidal preparations, including 2,4,5-T alone, were tried on smaller plots and on certain species. The brushkiller mixture and 2,4,5-T alone were tested in both oilbasal and foliage applications.

Although 2,4,5-T used alone had a minor part in the Gale River tests, the results there with this herbicide and in work reported by others established it rather firmly as the most promising material for further investigation. So in 1952 it was decided to restrict subsequent testing to this one herbicide, and to two types of treatment with it: water-foliage sprays at 4 pounds ahg (acid equivalent per hundred gallons), and oil-basal sprays at 12 pounds ahg.

Beginning in the spring of 1953, roadside work with these two treatments was started on the George Washington and Jefferson National Forests in Virginia, the Cumberland in Kentucky, and the Monongahela in West Virginia. The 
Monongahela tests included July, November, and March applications. Treatment units in all these tests comprised several miles of roadside--enough to provide some preliminary indications of time and cost requirements. Individual treatment units varied from 2.75 to 25 miles. All together, some 78 miles of roadside (equivalent to 39 miles of road) were treated in the testing program (table 1).

Table 1.--Miles of roadside and miles of telephone line treated on five National lorests, by treatment method

\begin{tabular}{|l|c|c|c|}
\hline \multirow{2}{*}{ Forest } & \multicolumn{2}{|c|}{ Roadside } & \multirow{2}{*}{$\begin{array}{c}\text { Telephone 1ine: } \\
\text { oil-basal }\end{array}$} \\
\cline { 2 - 3 } & Water-foliage & Oil-basal & \\
\hline George Washington & 6.4 & 6.0 & 2.0 \\
Cumberland & 25.0 & 8.4 & -- \\
Monongahela & 11.3 & 10.0 & 10.0 \\
Jefferson & -- & 11.2 & - \\
White Mountain & -- & -- & 1.2 \\
Total & 42.7 & 35.6 & 13.2 \\
\cline { 2 - 3 } & & & \\
\hline
\end{tabular}

Telephone line bordered road and was treated along with the roadside.

In addition, sectors of telephone line right-of-way, totalling 13.2 miles, were treated on the Monongahela, George Washington, and White Mountain National Forests. However, the line on the Monongahela bordered the test road, had been mowed in the past along with the roadside, and was included with the roadside in our test treatment (table 1). On the other two lines the woody growth had not been cut for perhaps 10 years, and consequently was much older and larger than most roadside brush; results on these lines are included in this report mainly because they supplement the roadside work.

A guiding principle in all the roadside and telephone line work was to spray selectively insofar as possible. For both aesthetics and soil stabilization it is desirable to retain the herbaceous and low shrubby vegetation. Moreover, a full cover of such low vegetation inhibits the establishment of tree seedlings and reduces the future maintenance job, as has been pointed out by Egler. 2

\footnotetext{
${ }^{2}$ Egler, Frank E. Right of way maintenance by plant-community management. Aton Forest, Norfolk, Conn. 19 pp., illus. 1949.
} 
Since all of the spraying was done with manually operated nozzles by men on foot, the spray could easily be directed onto undesirable plants and, for the most part, could be kept off the associated vegetation. Basal stem treatments can be restricted to specific plants somewhat better than foliage applications, but a good deal of selection could be done even in foliage spraying. Many patches and short stretches occupied only by herbaceous plants, or by such shrubby species as low blueberry and bunchberry, could be skipped entirely; scattered clumps of taller-growing brush could be spot-treated; only occasionally, where undesirable species formed practically a solid cover, was overall treatment unavoidable.

Thoroughness of application was emphasized in all the test work. Particularly in oil-basal spraying, the men were trained and supervised to soak every stem all around to the point of copious rundown. Experiments by Bramble, et al., in 1953 had clearly demonstrated the necessity to wet the root-collar area of every stem if resprouting is to be suppressed. 3 This principle was confirmed later in a somewhat similar experiment by McQuilkin. ${ }^{4}$

For each individual application of a treatment, except those on the Jefferson National Forest, 25 to 50 trees or sprout clumps of each of the more important woody species were marked for future observations. Wooden stakes bearing identifying symbols written with keel were used for markers. The intent was to check the kills after 1 and 2 years. However, a number of markers were molested, or frost-heaved, or simply could not be found later; so the final tallies usually represented fewer plants than were marked.

\footnotetext{
3Bramble, W. C., Worley, D. P., and Byrnes, W. R. Effect of placement of dormant basal spray on top-killing and sprouting of scrub oak. Northeast. Weed Control Conf. Proc.: 309-311. 1953.

McQuilkin, W. E. The key to effective basal spraying of woody plants: wet the root-collar. Jour. Forestry 55: 143-144. 1957.
} 


\section{RESULTS IN ROADS IDE AND TELEPHONE LINE TESTS}

These tests were not designed for statistical analysis, or to detect small differences among species or treatment variables. The main interest was simply to determine whether one or the other of the selected treatments would kill woody species well enough to be a practicable substitute for mowing. Kills are reported as percents based upon the numbers of marked plants found in the final tally. For non-suckering species, all reported kills are apparent root kills (stem base dead, no resprouting); for suckering species such as sassafras and black locust, kills were recorded if stems were dead with no new suckers showing within a radius of about 2 feet.

\section{Water-Foliage Spray}

This treatment generally failed to give satisfactory kills. Certain species, notably the birches, yellow-poplar, sassafras, and sumac, were knocked down fairly well by foliage sprays; but oaks, maples, ash, hickories, beech, and most conifers were mare or less resistant. In one instance (George Washington National Forest) kills in the range of 75 to 90 percent of some of these 'resistant' species were achieved with foliage sprays, but this was a case of spraying new sprouts in May after late-sumner mowing the preceding year. These plants evidently were weakened and more susceptible to the herbicide than are plants that had not undergone recent cutting.

As examples of typical kills of 'resistant' species, data from a Monongahela road may be cited. The sprouts here were in their second year of growth; a water foliage spray was applied in July 1953. In the fall of 1955, tallies of marked plants showed the following kills: red oak--10 percent, white oak--13 percent, beech--53 percent, white ash-45 percent, sugar maple--19 percent.

0

\section{Oil-Basal Spray}

This treatment resulted in high percents of root kill on almost all non-suckering species; root-suckering species were readily stem-killed but commonly exhibited some recovery in the form of new sucker sprouts originating a few 
inches to several feet from the original stems. Black locust is one of the most common species in this category; it definitely is the most troublesome because it grows considerably faster than most others.

Table 2 shows the kills of marked roadside plants on three forests (no data were obtained from the job on the Jefferson), as of the fall of 1955. This was two or two and a fraction growing seasons after the treatments were applied. More than half of the kill percents are based upon 25 or more plants; for the other figures something less than 25 marked plants were found in the final tally, but in only four instances were there fewer than 10 plants.

Table 2.--Kills of marked plants of various species by oil-basal treatment on roadsides of three forests, based on tallies in the fall of 1955

\begin{tabular}{|c|c|c|c|c|c|}
\hline \multirow[b]{3}{*}{ Species } & \multicolumn{5}{|c|}{ Forest and date of treatment } \\
\hline & \multirow{2}{*}{$\begin{array}{l}\text { George Washington } \\
\text { May } 1953\end{array}$} & \multirow{2}{*}{$\begin{array}{c}\text { Cumberland } \\
\text { June } 1953\end{array}$} & \multicolumn{3}{|c|}{ Monongahela } \\
\hline & & & July 1953 & November 1953 & March 1954 \\
\hline Oak, red & $\begin{array}{l}\text { Percent } \\
84\end{array}$ & $\begin{array}{c}\text { Percent } 1 \\
--\end{array}$ & $\begin{array}{l}\text { Percent } \\
79\end{array}$ & $\begin{array}{l}\text { Percent } \\
92\end{array}$ & $\begin{array}{l}\text { Percent } \\
75\end{array}$ \\
\hline Oak, white & -- & -- & 77 & -- & 81 \\
\hline Oak, chestnut & 82 & - & -- & -- & -- \\
\hline Oak, mixed & -- & 100 & - & -- & -- \\
\hline Hickory, mixed & 96 & 100 & - & - & -- \\
\hline Beech & -- & -- & 100 & 97 & 97 \\
\hline Ash, white & 91 & -- & 69 & 41 & 41 \\
\hline Maple, sugar & 90 & -- & 91 & 96 & 86 \\
\hline Maple, red & 93 & -- & -- & -- & - \\
\hline $\begin{array}{l}\text { Birch, yellow } \\
\text { and sweet }\end{array}$ & -- & - & 100 & 100 & 100 \\
\hline Basswood & 100 & -- & -- & -- & -- \\
\hline Yellow-poplar & 100 & 100 & -- & -- & -- \\
\hline Persimmon & -- & 98 & - & -- & - \\
\hline Gum, black & -- & 92 & -- & -- & -- \\
\hline Witch-hazel & 98 & -- & -- & -- & -- \\
\hline Sassafras & - & -- & 70 & 88 & 67 \\
\hline Sumac, staghorn & -- & -- & 92 & 75 & 94 \\
\hline Pine, shortleaf & -- & 77 & - & -- & -- \\
\hline Hemlock & 95 & -- & - & -- & -- \\
\hline
\end{tabular}

$\mathrm{Black}$ locust does not appear in the table. Plants of this species were not marked because we already had fairly good information on its reaction to $2,4,5-\mathrm{T}$, and it was so well represented on the roadsides that its behavior could be observed well enough without need of marked plants. 
Except for white ash, which is widely recognized as resistant to 2,4,5-T, the kills generally were satisfactory. The relatively poor results with sassafras reflect its recovery by root suckers. Shortleaf pine, encountered only on the Cumberland, exhibited a notable capacity to survive by generating new shoots along the lower stem, even after a complete brown-off of the foliage.

Insofar as can be judged from the test on the Monongahela, season of treatment has little effect upon amount of kill. This is of some significance in that it imposes no seasonal restrictions upon action programs.

Table 3 shows the kills of hardwoods, two growing seasons after treatment, on two telephone lines where the stems were much larger than those on the road shoulders. On the White Mountain line, in the northern hardwood type, the saplings and sprouts were up to 15 feet tall. The George Washington line ran through oak-type forest; the treated oak, hickory, and red maple were mostly sprout clumps ranging up to 10 feet tall; the root-suckering sassafras and black locust were mostly single stems of equal or greater height. In all probability, some of these stems had underground connections.

As with the smaller sprouts on the roadsides, the common hardwoods, except white ash, were satisfactorily

Table 3.--Fills of marked plants two growing seasons after oil-basal treatment on telephone lines on two forests

\begin{tabular}{|c|c|c|c|}
\hline \multicolumn{2}{|c|}{ White Mountain } & \multicolumn{2}{|c|}{ George Washingt on } \\
\hline Species & Kill 1 & Species & $\mathrm{Kil1}{ }^{2}$ \\
\hline & Percent & & Percent \\
\hline White ash & 37 & Mixed oaks & 92 \\
\hline Red maple & 92 & Mixed hickories & 100 \\
\hline Sugar maple & 90 & Red maple & 95 \\
\hline Striped maple & 97 & Sassafras & 100 \\
\hline Yellow birch & 89 & Black locust & 95 \\
\hline Beech & 100 & & \\
\hline Black cherry & 89 & & \\
\hline Ironwood (Ostrya) & 94 & & \\
\hline
\end{tabular}

${ }^{1}$ Figures based upon $18 \mathrm{plants}$ each of black cherry and ironwood, upon 35 to 40 plants of all others.

${ }^{2}$ Figures based upon 21 to 25 plants. 
killed. The kills of sassafras and locust are, of course, not absolute; kills were recorded whenever a stem was dead and no new suckers had appeared in the immediate vicinity (within about 2 feet). This, however, was an arbitrary standard; the lateral roots of these species are widespreading and suckers arising 5,10 , or more feet away could easily be on the same root with a killed stem.

Coniferous species--mostly white pine, balsam fir, and red spruce--also were well represented on the White Mountain line. Sizes ranged up to saplings 8 feet or more tall. Seedlings up to about 3 feet tall usually were given a drenching overall foliage and stem spray, and were killed. Larger trees were basal-sprayed in the same manner as the hardwoods. As is now generally recognized by brush-control workers, most conifers beyond small seedling sizes are relatively resistant to $2,4,5-\mathrm{T}$ in both foliage and basal applications. This was confirmed in the White Mountain test: the kill, exclusive of the drenched seedlings, was estimated to be about 25 percent.

\section{APPRAISAL AND DISCUSSION OF RESULTS}

The tests demonstrated that the common woody roadside vegetation in our eastern forests could be controlled with an oil-basal spray of $2,4,5-\mathrm{T}$ at 12 pounds ahg. This treatment was sufficiently effective to be considered a practicable replacement for mechanical mowing. On species that do not root-sucker, white ash excepted, thorough application can be expected to give around 80 percent or better rootkills. Kills of ash may be only 50 percent or less, but since ash seldom is a predominant roadside species, it does not pose a great problem. Root-suckering species, of which black locust is the most common representative, are easily top-killed but often regenerate from the roots. Particularly on the more southern forests of the region, black locust is the most troublesome species to control under a regime of periodic oil-basal spraying with 2,4,5-T.

Water-foliage spraying is not regarded as having an important place in our road-maintenance work. It is much less effective than oil-basal treatment in terms of root kill and, if applied selectively (by manually controlled 
nozzles), the cost per application would not be a great deal less than for oil-basal. Costs per application and, possibly, average per-annum costs could be reduced by mechanized blanket foliage applications with a spray boom or mist blower. That is the method recommended or practiced on some national forests in other parts of the country. Madison, for instance, recommends mechanized blanket foliage sprays as practical on the forests of the Pacific Northwest, although recognizing that most of the brush will not be rootkilled, and that retreatment at intervals of 2 to 4 years will be required. 5

For reasons of aesthetics, public relations, and roadside soil stability, we never have seriously considered blanket foliage spraying for Region 7 national forests except, possibly, for a few special situations where this method might be effective and easier to apply than basal treatment. A road bordered by dense alder thickets or by a dense growth of small birches (both sensitive species) might be considered for blanket foliage treatment, particularly if it were a utility road that was not much used by the public.

Our basic policy, adopted during the testing period and unchanged today, is to rely mainly on the selective basal method. By so doing we (1) minimize objectionable mass brown-offs; (2) save most of the desirable low vegetation; and (3) accomplish maximum root kills, thereby stretching the tolerable interval between treatments to the maximum. Although selective oil-basal treatment may cost somewhat more per application, average per-year costs for brush control were expected to be no higher than under a water-foliage regime, and control would be achieved with a minimum of undesirable side effects. As will be shown later in discussing the action program, these expectations in general have been realized.

\footnotetext{
${ }^{5}$ Mad is on, Robert W. Three types of treatment kill brush, make roads safe, easy to maintain. Timberman Vol. 60 (13): 38-39, 68. 


\section{Spray Equipment}

The development of safe and efficient equipment, adapted to the specific job of selective spraying on forest roads, was an important part of the testing program, and has continued into the present action program. For efficient and economical operation it was necessary that the work be mechanized as much as possible. Therefore power sprayers are used for nearly all routine roadside work. The power rigs are supplemented by backpack hand sprayers for use in places that can not be reached conveniently by the power equipment.

\section{POWER SPRAY RIGS}

The basic pumper unit for the power spray rigs is of the type commonly used in fire suppression work; in fact, these pumpers are maintained on the national forests for dual service in both brush-control and fire-control operations. Since standard hose connections and adapters are used on both intake and discharge sides of the pump, the unit can be converted from a sprayer to a fire-control pumper or vice-versa in a matter of minutes.

The pump is a gear-type Pacific Marine with a capacity of 17 gallons per minute at 250 pounds pressure. Power is supplied through a direct-drive connection by a 5-horsepower, air-cooled engine; pump, engine, and a 175-gallon tank are mounted on wooden skids for convenience in slipping on and off the bed of a truck. With empty tank the outfit weighs 585 pounds; with full tank, almost a ton. Thus it may be used on a 1-ton pickup or other truck of suitable capacity (fig. 2).

The relatively high pump capacity that is needed for use in fire-fighting affords considerable recirculation and agitation of the herbicidal mixture when the outfit is used for spraying. In addition, a hydraulic jet-type agitator, installed near the bottom of the tank, assures constant uniformity of the mixture. This feature is largely superfluous when using oil solutions of 2,4,5-T ester, but is desirable for the occasional instances when water emulsions may be used. 


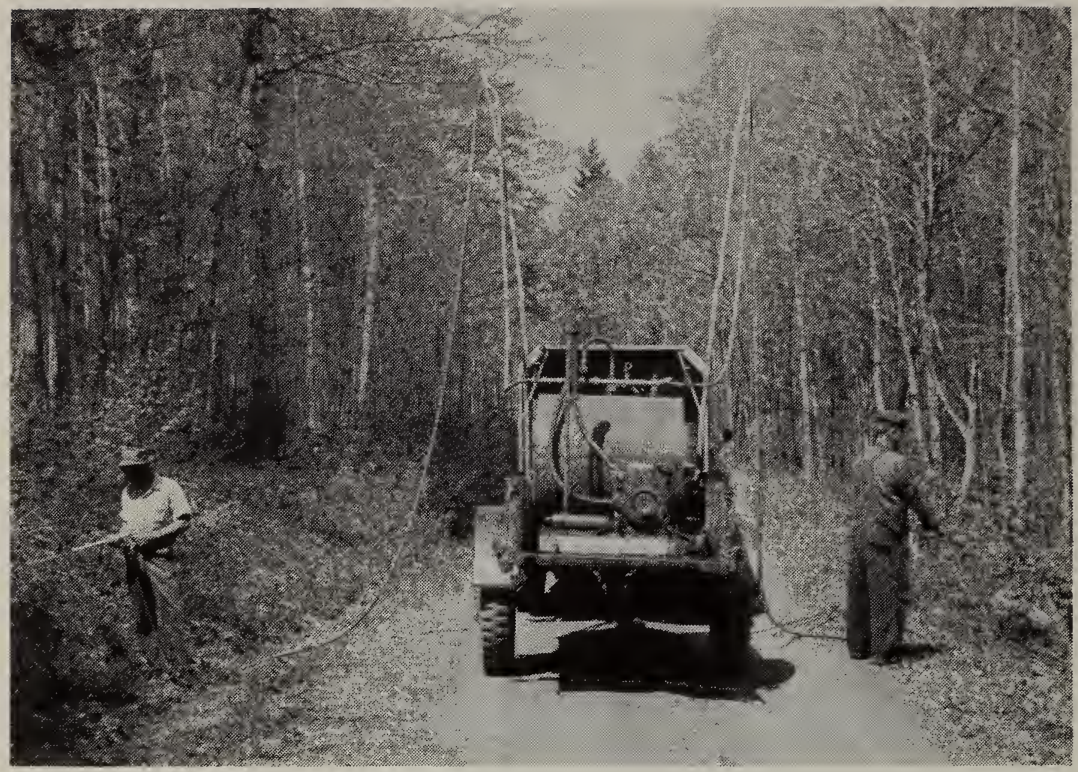

Figure 2.--A power sprayer, converted from a standardmodel fire-control pumper, in use on a road on the Monongahe la National Forest. The poles hold surplus hose off the ground and out of the way when spraying close to the truck, as shown here. When the full length of the hose is needed, it is easily available.

Two lengths of $3 / 8$-inch oil-resistant hose, each about 30 feet long and equipped with wand, nozzle, and shutoff valve, are attached to the pump outlet. Each hose and wand assembly is operated by a man on the ground; usually one man works each side of the road as the truck and sprayer ease along (fig. 2).

\section{HAND PUMPS}

Efficient, properly equipped hand pumps are nearly as effective as power rigs in many situations, particularly for basal spraying where high pressures are not important. Of course they are harder to carry and manipulate than the power equipment, and are little used on accessible roadsides. However, there is need for them in treating areas that are not easily accessible to a power rig. Such areas include parts of many camping and picnic grounds, some foot trails 

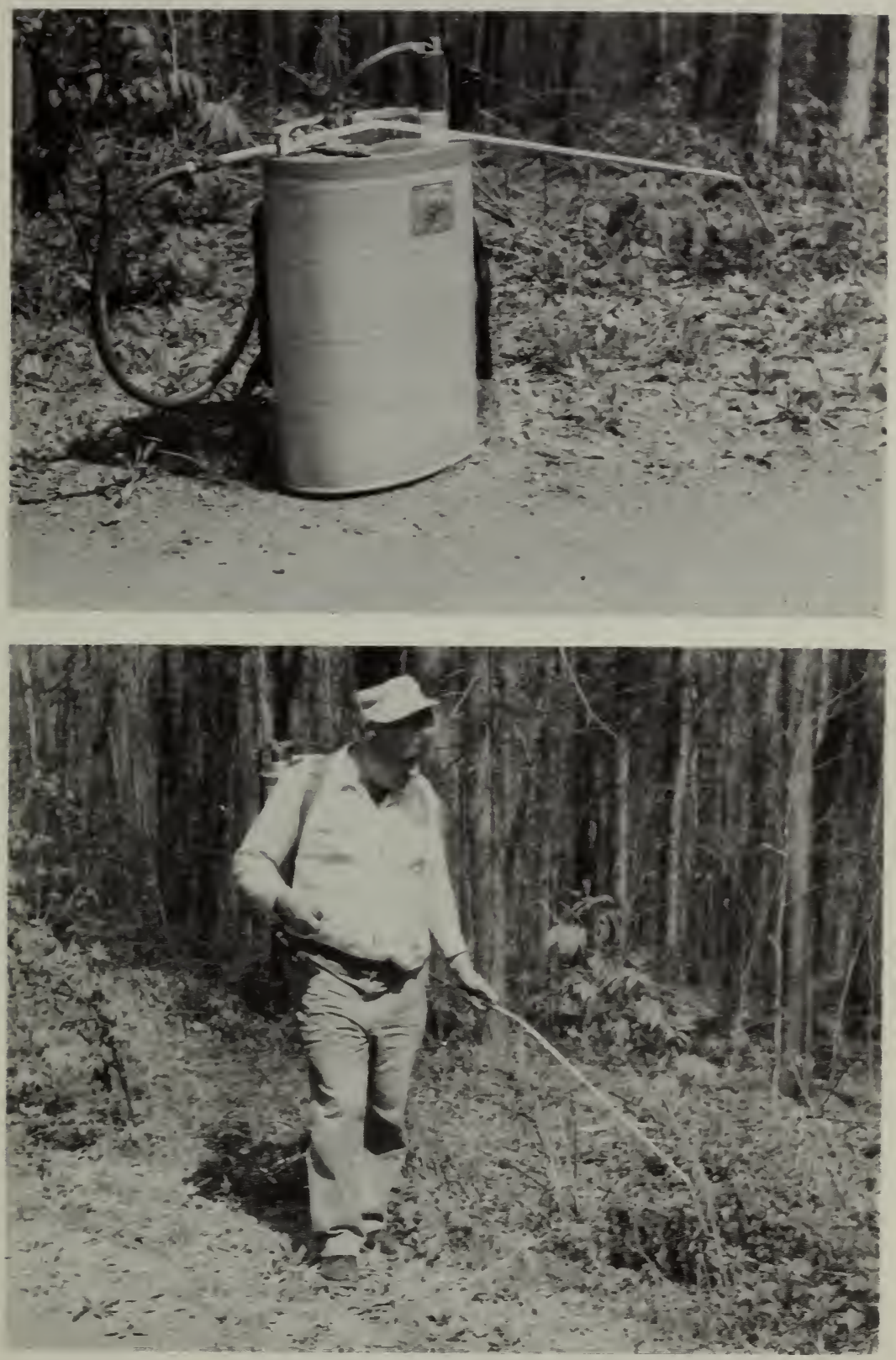

Figure 3.--A. Back-pack sprayer of the type used in Region 7. Manufacturer's hose, wand, and valve assembly has been-replaced by higher quality, better designed equipment. Side lever is on opposite side of tank in this view. B. Back-pack sprayer in position for use. Lever is grasped by man's right hand. 
around high-use recreation spots, and the inside vistas of sharp curves in forest roads. Three hand pumps are carried as a standard complement with each power spray unit.

Region 7 has tried various types and brands of hand pumps, and has done some work in modifying certain components of several production models. From this experience, a backpack type of hand sprayer with a stainless steel tank of about $4 \frac{1}{2}$-gallon capacity, with built-in pump and agitator operated by a side lever, has been adopted as standard (fig. 3).

For more efficient operation and to protect the operator from leakage, the regular hose and wand assemblies of manufacturers' units were replaced with tailored 1/8-inch aluminum wands threaded for adapters without gaskets or washers; high-quality, no-leak, trigger-type cut-off valvies; and oil- and chemical-resistant hose fitted with threaded steel or brass couplings and circle clamps.

\section{NOZZLES AND TIPS}

Efficient spraying requires well-made nozzles and tips of a type that is adapted to the particular job at hand. Use of the wrong type of nozzle assembly results in waste of spray material, higher costs for both material and labor, and may result in poorer application and poorer kills. Each spray crew should carry a selection of nozzles suited to the different conditions they are likely to encounter.

Nozzle performance and spraying efficiency are affected by the operating pressure. By regulating engine speed and the valves that control re-circulation of the liquid, desired pressures can be maintained. Basal spraying is best done at moderate pressures; foliage spraying, especially in dense or tall brush, requires higher pressures to accomplish good coverage. As a safety measure, power sprayers must be equipped with a pressure gage. 
After trying a number of nozzle and pressure combinations, Region 7 has adopted the following standards:

\section{Basa 1 Spraying}

For stumps or scattered stems of $2 \frac{1}{2}$-inch basal diameter and larger: wide-angle cone-type nozzle at 40 to 60 PSI (pounds per square inch).

For stumps or scattered stems less than $2 \frac{1}{2}$ inches in diameter: medium-angle cone-type nozzle at 40 to 60 PSI.

For dense, small brush: wide-angle fan-type nozzle at 40 to 70 PSI.

\section{Foliage Spraying}

For tall or dense brush: medium-angle cone-type nozzle at 150 to 175 PSI.

For scattered small brush: medium-angle fan-type nozzle at 50 to 70 PSI.

The above standards are for power spraying. Nozzles and tips are interchangeable between power and hand sprayers, but pressures above 40 PSI or so are not readily attainable with hand pumps.

Additional details and specifications for any of the equipment mentioned above, and names of manufacturers, may be obtained from the U. S. Forest Service, 6816 Market Street, Upper Darby, Pennsylvania. 


\section{Brush Control in Practice on the National Forests}

The seven national forests in Region 7 maintain about 1,700 miles of road. The original plan for conversion from annual mowing to chemical brush control on all national forest roads called for a gradual change-over in 5 years, beginning in 1956. As of 1959 one forest--the George Washington--had completed the change-over, all their roads having been sprayed at least once. The other forests, now in various stages of transition, are expected to have all their. roads under chemical control, as scheduled, by July 1961.

One of the crucial tests of a new method for doing any $\mathrm{job}$ is its acceptance by the people who actually apply or use it. On the national forests, use of chemicals for controlling roadside brush has passed this test with flying colors. True, some of the men at first have been hesitant to make the change either because of inertia, or fear of adverse public opinion, or because of sentimental admiration for the groomed look that mowing temporarily confers upon a roadside. But after a year or two of experience with spraying, these attitudes have usually changed. Most national forest personnel with whom we have discussed the subject, from supervisors down, are sold on chemical brush control. Particularly impressive has been the unprompted enthusiasm displayed by several of the road-maintenance foremen.

\section{ADVANTAGES OF THE CHEMICAL METHOD}

What, precisely, are the advantages of herbicidal control over mowing? And why do road-maintenance men prefer the sprayer to the mower?

1. Spraying

Is More Economical

The average cost for mowing prior to 1956 was about $\$ 16$ per year per mile of road. The average initial cost per mile of road for selective oil-basal spraying is about $\$ 45$. But one properly done chemical treatment is good for at 
least 5 years; thus the cost per year is $\$ 9$, whereas the $\$ 16$ mowing job must be done every year. On this basis, chemicals can be expected to reduce brush control costs by more than 40 percent. Actually, some of the earlier spray jobs are holding so well that our estimated 5-year treatment interval appears to be very conservative: except where black locust is abundant, we believe, many roads will hold as long as 8 years or more without re-treatment--with proportionately greater savings in maintenance costs (fig. 5 ).

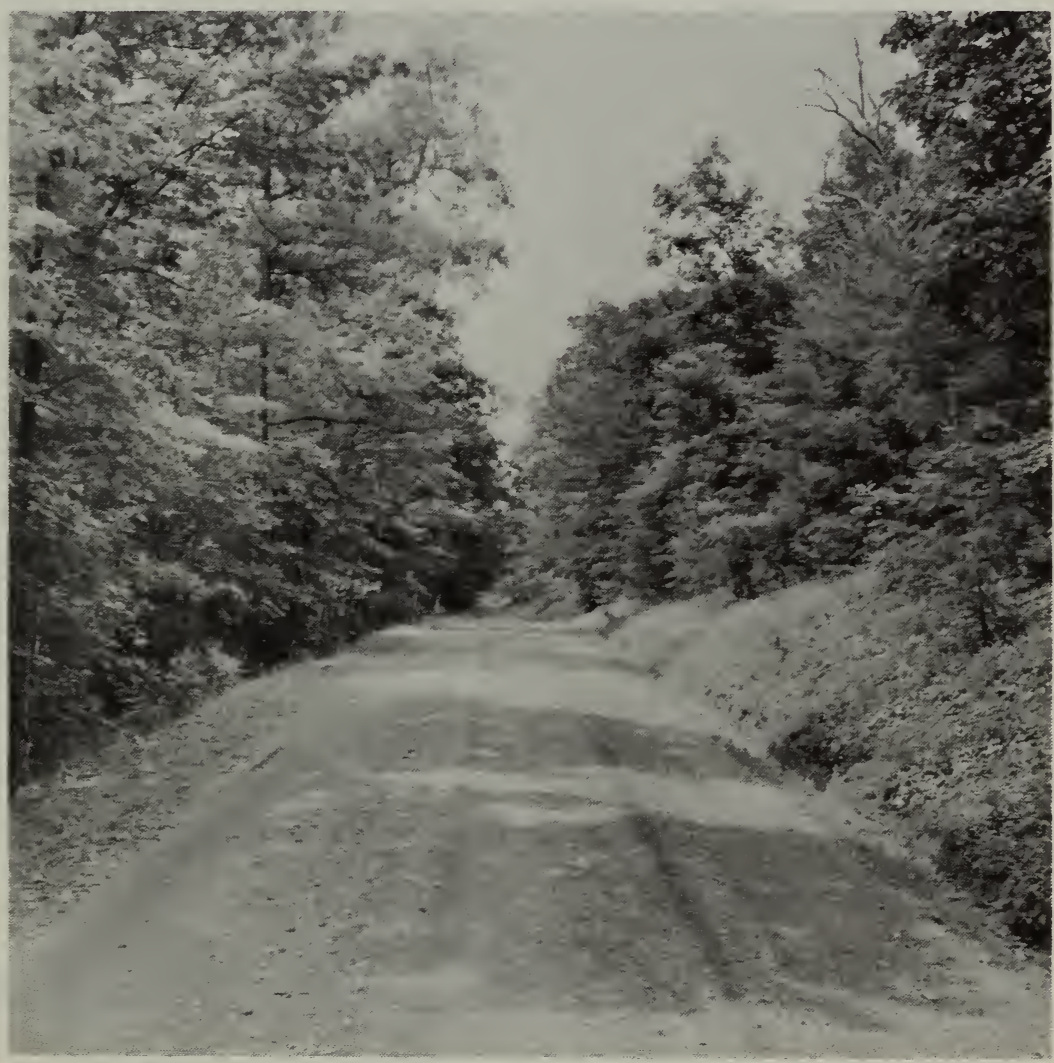

Figure 4.--A road on the George Washington National Forest 2 years after spraying in 1957. Shelf construction along a slope, with bank on one side and drop-off on the other, is typical of many forest roads. With selective oil-basal spraying, the bank remains stabilized under herbaceous cover. Compare this with Figure 1. 
Moreover, the capital cost of spray equipment is considerably less than that for mowing equipment, maintenance costs for spray equipment are lower, and less time is lost from breakdowns. Although these items are reflected in the per-mile costs cited above, they merit special mention.

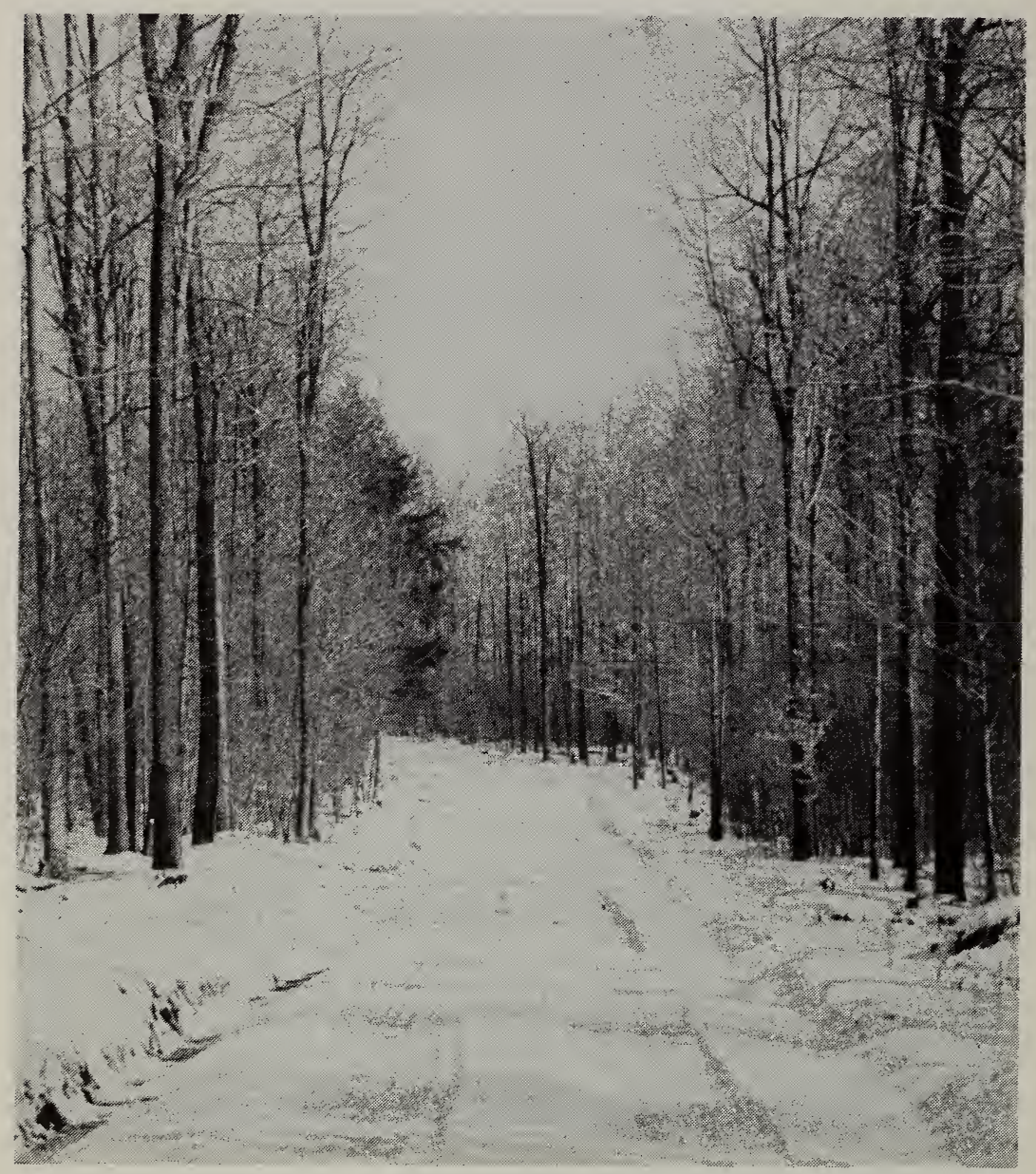

Figure 5.--A road on the Allegheny National Forest 5 years after oil-basal and stump spraying in 1954. Large brush, which under mowing maintenance had been allowed to grow up along the edge of the timber, was cut and the stumps were treated. Very little woody regrowth has developed here; this road can stand several years more before retreatment will be required. 


\section{Spraying}

Is Easier Work

Driving a power mower is a trying job, as the operator must be ever vigilant in maneuvering his machine along sloping road shoulders, avoiding rocks, ditches, and other hazards. In addition to the machine mowing, it is necessary to do considerable hand cutting with scythes and brush-hooks, and occasionally with axes and saws, in clearing around guard rails and culvert heads, and in 'daylighting' curves in the road.

Spraying is a much more relaxed type of labor. The truck driver moves slowly down the middle of the road, and the physical demands upon the nozzle-men are light compared to scythe or brush-hook work. Spraying with the backpack outfits of course is more laborious, but ordinarily this is required only intermittently and thus does not become burdensome.

\section{Spraying Permits}

\section{Greater Flexibility On The Job}

Mowing usually has been limited to one swath of 5 or 6 feet; to cut back farther requires a second pass and practically a doubling of the costs for the mileage so treated. Spraying, on the other hand, can be varied to fit the situation from spot to spot: 3 or 4 feet may be adequate here; 8 or 10 feet of clearance may be desirable there; and on curves treatment with the power outfit can be extended 20 to 30 feet from the road edge--and farther, if necessary, by use of hand sprayers.

\section{Spraying Permits Greater}

Flexibility in Work Programming

Mowing is limited to a period of 2 months or so in mid and late summer. Because of the necessity to get over all the roads in a limited time, the job exerted a relentless pressure on the responsible foremen each year. But oil-basal or stump spraying can be done at almost any time when the ground is free of snow. And if a spray job scheduled for one year has to be postponed until the next year, no significant complications will ensue; the crews simply 
will have to cover a little more mileage the next year. So, under chemical control, it is much easier for maintenance men on the forests to balance their work programs and to adjust them as conditions may require.

\section{Recommendations ${ }^{6}$}

Methods of Treatment

As a general policy for controlling brush along established roads on eastern forests, selective basal spraying with low-volatile 2,4,5-T ester in oil at a concentration of 12 pounds ahg is recommended. When new roads are built, the same herbicidal solution may be used as a stump spray immediately after the original or capital clearing. If a neglected or abandoned road, bordered by dense, tall brush is to be renovated, such brush should be cut and the stumps treated as on capital clearings.

All oil-basal spraying on either standing stems or stumps should be rigorously selective. Treat only undesirable species; cut off the spray when moving from one stem or stump to the next; save as many herbs and low-growing shrubs as possible, not only for aesthetic reasons, but also because these plants stabilize the soil, furnish food for wildlife, and inhibit the re-establishment of undesirable woody species. In further deference to aesthetic values, scattered specimens of the taller ornamental species, such as dogwood, redbud, laurel, and holly, may be left wherever they will not constitute a nuisance.

Water-foliage spraying is suggested as an alternative method for those occasional situations in which the predominant species are controlled about as well by one method as the other; such species include alder, all birches, sassafras, sumac, black locust, and yellow-poplar. By using the water-foliage method, modest savings in material costs are possible. However, roadsides on which only sensitive spe-

${ }^{6}$ See also: Roadside spraying with chemicals--Manual for For emen. U. S. For est Service, Region 7, Upper Darby, Pa. 22 pp. 1959. 
cies occur will be encountered so seldom, or over such short stretches, that spray crews ordinarily will not find it worth while to change methods.

If a water-foliage spray is to be used, the recommended mix is 4 pounds ahg of low-volatile 2,4,5-T ester in water, or in a 10-percent oil-in-water emulsion. The addition of oil is suggested particularly for any foliage spraying done toward the latter part of the growing season. Formulations of 2,4,5-T designed especially for use in oilwater emulsions are available; however, with agitation, the regular formulations can be used. For best results in foliage spraying, use pressures of 150 PSI or more, and completely wet all foliage and stems.

\section{Proper Chemicals}

Only the low-volatile esters of 2,4,5-T should be used. For use on the national forests, chemicals must meet Federal Specification 0-H-210a for Type II, which jesignates the liquid ester form of 2,4,5-T, and Class 2, which designates esters of low volatility. We do not recommend use of mixtures of 2,4,D and 2,4,5-T on the usual run of eastern forest species.

The oil used in our work has been mostly diesel oil, and we have made no comparisons with other oils. However, according to manufacturers' labels, No. $l$ and No. 2 fuel oil, and kerosene are equally as good as diesel oil.

\section{Crew Training \\ and Proper Application}

Thorough training of spray crews is important. Most instances of poor or mediocre results in our roadside spraying can be charged to inadequate training of crew members. Foremen and nozzlemen must know the common woody species-the ones to treat and the ones to save. Moreover, they must be able to recognize these species both in leaf and in dormant condition, as oil-basal spraying may be done at any season when the ground is bare of snow. Second, the crewmen must appreciate the importance of thorough application, and be conscientious enough to do the job right. Thoroughness means soaking every stump or stem base so copiously that the 
root collar zone, which may be several inches beneath the surface of the litter, is completely wetted. Particularly on the more resistant species, such as the maples and ash, failure to wet this zone leaves dormant buds uninjured and capable of generating new sprouts. Well-trained, careful nozzlemen recognize that certain species are harder to kill than others, and treat resistant ones somewhat more intensively.

\section{Re-treatment}

It has been stated above that most properly treated roads are expected to stand at least 5 years between treatments, and that some roads might stand several years longer. No doubt there will be much variation from one piece of road to another, depending upon soil characteristics, topographic position, aspect, species composition of the bordering forest, and canopy development over the roadway. Possibly there will be differences between the northern and southern forests of the Region. Obviously 5 years is only a tentative estimate of about how long most roads might stand between treatments. In practice on the forests, maintenance foremen simply will watch their roads and schedule retreatment as it becomes necessary, be it 5 years, 7 years, or any other interval.

Retreatment, when it becomes necessary probably will be a lighter job on most roads than the first treatment. So far, we have only one good comparison of a retreatment job versus the original treatment: On the George Washington National Forest, a 13.6-mile road that was first sprayed early in 1956 was resprayed, after 5 growing seasons, late in 1960. The original brush was a heavier-than-average growth of mixed oaks; 100 gallons of herbicide were used per mile, and the cost per mile was $\$ 58.50$. In 1960 , the brush density was considerably less, as evidenced by use of only 59 gallons of herbicide per mile. Despite somewhat higher unit costs for both labor and materials, the retreatment was done for $\$ 34.50$ per mile.

The retreatment question generally will arise soonest on those roads where considerable black locust is present. There doubtless will be situations where the locust will require attention several years before associated species have 
made much comeback. For such situations we suggest consideration of a light, touch-up treatment, which mostly would be restricted to the larger locust stems, and could be done fairly quickly and cheaply by a 2- or 3-man crew cruising the roads in a light truck and carrying only back-pack sprayers.

In this connection, some simple administrative tests of other chemicals on black locust are recommended. Aminotriazole, in particular, applied as a foliage spray, has been reported to kill the stems of locust and to suppress sucker regrowth markedly better than $2,4,5-\mathrm{T} .{ }^{7}$ If the established locust root systems actually could be killed, it probably would be 10 years or so before locusts from seed regeneration again would become a special problem.

\section{Summary}

Because of the excessive costs of mowing the 1700 miles of road each year on the seven national forests in Region 7, tests of chemical methods of brush control were started in 1951 and continued on five forests through 1955.

Results of the tests indicated that roadside brush could be satisfactorily controlled by an oil-basal spray of $2,4,5-T$, selectively applied, and that the costs would be less than for annual mowing.

In 1956, a 5-year program for converting entirely from mowing to chemical control on all Region 7 forests was started. One forest completed the conversion in 1959; the others are expected to finish on schedule by July 1961.

During the testing period and since, relatively simple modifications of standard-model slip-on fire pumpers have been perfected for converting the pumpers into power sprayers. Since the pumpers can be converted from one use

7 Jeffers, W. A. Late-season foliage applications of aminotriazole and amino-triazole-benzoic combinations on black locust. Northeast. Weed Control Conf. Proc. 14: 383-392. 1960. 
to the other in a few minutes, only a small investment in spray equipment is required. Back-pack sprayers, also somewhat modified from production models, are used to supplement the power outfits.

Experience to date indicates that most properly sprayed roadsides can stand at least 5 years, and often longer, before retreatment will be required. With a 5-year interval, brush control costs with chemicals are averaging about 40 percent less than costs for mowing. 




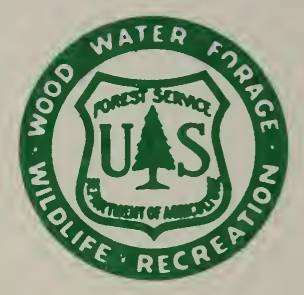

